Archives of Natural History, 47, 147-165. Accepted version.

\title{
Robert McCormick's geological collections from Antarctica and the Southern Ocean, 1839-1843
}

\section{PHILIP STONE}

British Geological Survey, The Lyell Centre, Research Avenue South, Edinburgh EH14 4AP, Scotland, UK (e-mail: psto@bgs.ac.uk)

\begin{abstract}
Robert McCormick (1800-1890) took part in three mid-nineteenthcentury British Polar expeditions, two to the Arctic and one to the Antarctic. The latter, from 1839 to 1843 and led by James Clark Ross, is the best known. McCormick served as senior surgeon on HMS Erebus and was responsible for the collection of zoological and geological specimens. Despite the novelty and potential scientific importance of these early geological collections from Antarctica and remote islands in the Southern Ocean, they received surprisingly little attention at the time. Ross deposited an official collection with the British Museum in 1844, soon after the expedition's return, and this was supplemented by McCormick's personal collection, bequeathed in 1890. McCormick had contributed brief and idiosyncratic geological notes to the expedition report published by Ross in 1847, but it was not until 1899 that an informed description of the Antarctic rocks was published, and only in 1921 were McCormick's palaeobotanical specimens from Kerguelen examined. His material from other Southern Ocean islands received even less attention; had it been utilized at the time it would have supplemented the better-known collections made by the likes of Charles Darwin. In later life, McCormick became increasingly embittered over the lack of recognition afforded to him for his work in the Polar regions. Despite that contemporary neglect, his collections from the Ross Antarctic expedition provide unique insight into the geological work of nineteenth-century British naval surgeons.
\end{abstract}

KEYWORDS: Antarctic exploration - polar science - James Clark Ross - Joseph Hooker - Charles Darwin - Ross Sea - HMS Erebus - Kerguelen - Falkland Islands - geology.

\section{INTRODUCTION}

The British Royal Navy surgeon Robert McCormick (1800-1890) played only a minor role in nineteenth-century Polar exploration, but his two-volume, self-published autobiography (McCormick 1884) has secured him a measure of celebrity (Figure 1). ${ }^{1}$ A rather loquacious work of self-promotion, it has been the starting point for two biographies: the first (Keevil 1943) is a charitable account, the second (Jones 1982) a more critical appraisal. More recently, McCormick's professional situation has been assessed (Steel 2011); he has been included in the Dictionary of Falklands Biographies (Savours 2008) and he has enjoyed favourable treatment in a bestselling popular book (Palin 2018). He occasionally styled himself M'Cormick.

McCormick was born near Great Yarmouth, Norfolk, on 22 July 1800. His family came from Northern Ireland, and his father, also Robert, had been a Royal Navy surgeon but was lost at sea in the wreck of HMS Defence off Jutland on 24 December 1811. The younger Robert followed his father into the Royal Navy as a surgeon in 1823, having studied medicine at Guy's and St. Thomas's hospitals, London, in 18211822, and was first deployed to the West Indies. Two years later, suffering from yellow fever, he was invalided back to England and then, after some coastal duties, 
made "every effort in my power to get out with Captain Parry in his proposed expedition to attempt to reach the North Pole" (McCormick 1884: 2: 196). His efforts succeeded: he was appointed Assistant Surgeon to HMS Hecla and sailed for Spitsbergen (Svalbard), in March 1827. McCormick was not one of the team that set out unsuccessfully for the Pole but remained with HMS Hecla in Spitsbergen. ${ }^{2}$

For McCormick, perhaps the most important outcome of the Spitsbergen voyage was the profound impression that the island made on him, an impression that initiated a long-term interest in the Polar regions. He subsequently made extended voyages to both the Arctic and the Antarctic, and it is the latter region, and the 1839-1843 expedition of HMS Erebus and HMS Terror led by James Clark Ross (1800-1862), which is considered in this paper.

McCormick's interest in natural history was very much focused on birds, which he shot at every opportunity, but during his travels he also collected many geological specimens, both rocks and fossils. This paper revisits McCormick's geological collections from the Antarctic regions (Figure 2), reviews their research history, if any, and considers their potential contemporary significance, had they received prompt and informed attention at the time. Complementary information has been obtained from McCormick's original diaries and notebooks, which are held in the Wellcome Collection, London. ${ }^{3}$

\section{THE SPECIMENS}

Woodward and Fletcher (1904: 391) confirmed that in 1844, very soon after the return of the Ross expedition, 702 rock specimens were deposited with the British Museum; these will be referred to hereafter as the Ross Collection. Some specimens were acquired during the expedition's visits to various Atlantic Ocean islands, South Africa, Tasmania and New Zealand, but the majority are from the Southern Ocean and Antarctic regions. ${ }^{4}$ Most of the specimens are likely to have been collected by McCormick, and for some this is confirmed by reference in the registration details to collectors" numbers such as "No 21 of McC". However, for other specimens there is reference to numbers such as "No 103 of JR", who may have been either James Clark Ross (who had a strong personal interest in natural history) or, more probably, John Robertson, surgeon of HMS Terror; specimens may also have been acquired by the expedition's other officers.

McCormick also retained a personal collection, which, on his death in 1890, was bequeathed to what had become the British Museum (Natural History). As accepted, the McCormick Bequest comprised:

1. "250 fossils, chiefly Brachiopoda, collected by him in the Arctic regions, Madeira, Tasmania, the Falkland Isles, and Kerguelen Land" (Woodward and Fletcher 1904: 308).

2. "A selection from the rock specimens collected by him during the Arctic Expedition of 1827, Antarctic Expedition of 1839-43, and the Franklin Search Expedition of 1852-53" (Woodward and Fletcher 1904: 432).

Given the limited knowledge of the Polar regions in the mid-nineteenth century, the Ross Collection might have been expected to generate some scientific interest. Surprisingly, this did not happen. There was a belated petrographical study of 
Antarctic rocks (sensu stricto) from the combined Ross Collection and McCormick Bequest (Prior 1899), but this was entirely descriptive, and unfortunately did not cite the Museum registration numbers of the specimens examined. Some commentators have drawn attention to McCormick's extant zoological specimens: for example, Steel (2011: 34) notes that "the Department of Zoology at the Natural History Museum still holds some of McCormick's specimens from the Erebus voyage". These may include all or some of the "142 birds and eggs from the Falkland Islands and Antarctic seas" that Keevil (1943: 61, note 27) records were bequeathed to the British Museum, presumably in 1890. In contrast, none of his biographers have acknowledged McCormick's geological contributions.

McCormick's geological specimens are now held by the Natural History Museum, London (NHM). This was established as a separate branch of the British Museum in 1881 and was at first known as the British Museum (Natural History). It only became an independent institution as recently as 1965.

\section{THE BEAGLE DEBACLE, 1831-1832}

Following the Spitsbergen expedition, McCormick spent a considerable period either without a ship on half-pay or on sick leave, but at the beginning of 1830 he again sailed for the West Indies; he remained there only a few months, invalided back to England in June. Once more on half-pay, McCormick attempted to get more congenial postings, but failed, and instead decided to attend the natural history and geology lecture course given by Professor Robert Jameson (1774-1854) at Edinburgh University. This was a major undertaking involving 97 lectures between 3 November 1830 and 15 April 1831; in addition he followed courses in medicine and anatomy. ${ }^{5}$ Reflecting on this experience, reiterating an original diary entry dated 21 June 1831, he wrote in his autobiography: "[h]aving now fairly taken up the pursuit of natural history, in addition to my ordinary professional duties, and prepared and qualified myself by a course of hard study and attendance on the lectures of the most distinguished professors, my great object was to get employed in scientific voyages of discovery" (McCormick 1884: 2: 217-218)

It might seem from his autobiography that McCormick was thwarted in his ambition to pursue natural history, the next period of his life being dismissed as "three years ... spent in two small miserable crafts", of which the first was a "surveying tengun brig" (McCormick 1884: 2: 218-219). The "ten-gun brig" on which he sailed for South America in December 1831 was none other than HMS Beagle, commanded by Captain Robert FitzRoy (1805-1865). Things did not work out well for McCormick, and his unfortunate legacy from the voyage is to be remembered best for what he failed to do. He must have initially welcomed the desired opportunity to establish his reputation as a naturalist, but finding that role aboard HMS Beagle had been usurped by the young Charles Darwin (1809-1882), McCormick left the ship in Brazil, "invalided" once again. As is well known (Steel 2011), he was not missed by Darwin or FitzRoy, both of whom found him tiresome and scientifically passé.

The Beagle experience left McCormick embittered. Throughout his autobiographical accounts, McCormick (1884) takes pretentious pride in relating his meetings with prominent naval figures, scientists and aristocrats, and as one would expect from a naval officer, conscientiously names the ships on which he served. As previously noted by Ross (1982: 32), the exceptions are Darwin and the Beagle, the former never named, and the latter dismissed rather contemptuously as simply "a ten- 
gun brig". ${ }^{6}$ So successful was McCormick in concealing this connection that his first biographer (Keevil 1943) and the obituarists identified by Steel (2011:4) all overlooked the Beagle interlude.

Post-Beagle, McCormick was deployed again to the West Indies, but once more contracted yellow fever and returned to England as an invalid. There followed a long period of effective unemployment on half-pay. Still, hoping to make a name for himself as a naturalist and to erase the Beagle disappointment, in early 1838 he began to lobby vigorously for a place on the Antarctic expedition then being planned under the leadership of James Clark Ross, in command of HMS Erebus and HMS Terror. In this he was successful, perhaps helped by Ross having been an officer on Hecla during the 1827 Spitsbergen voyage, and on 10 April 1839 McCormick was appointed as a senior surgeon to the Antarctic expedition. Ross's primary ambition was to locate the South Magnetic Pole; he had previously located the North Magnetic Pole during an Arctic expedition in 1831 (Dodge 1973:141; Ross 1982: 9, 19-20).

\section{THE EREBUS AND TERROR ANTARCTIC EXPEDITION, 1839-1843}

When he joined HMS Erebus, McCormick discovered that his assistant surgeon was to be the young botanist Joseph Hooker (1817-1911). This situation had the potential for a similar conflict of interests to that which had developed aboard the Beagle, but, on this occasion, McCormick was mollified by an official difference in rank. Hooker had a junior Naval appointment, whereas Darwin had been supernumerary to HMS Beagle's crew, and effectively the Captain's guest. Ross had also clarified that McCormick was to have responsibility for zoology and Hooker for botany (McCormick 1884: 2: 278-279; Ross 1982: 33). McCormick (1884: 2: 279) noted proprietarily that "meeting Captain Ross in the dockyard, I took the opportunity of calling his attention to the geology." In the event, McCormick showed little interest in anything but large mammals, ornithology (that is, shooting and skinning birds) and collecting geological specimens. By default, Hooker assumed responsibility for the considerable collections of marine invertebrates that were made during the expedition. Writing to his father from the Cape of Good Hope on 17 March 1840, Hooker rejoiced that "McCormick takes no interest in any thing but in bird shooting, \& rock collecting ... I am nolens, volens [willing or unwilling] the naturalist ...".

Nevertheless, McCormick and Hooker remained on good terms throughout the voyage. Their respective interests were aided by the commitment of Ross, who was himself a natural history enthusiast and actively collaborated with both men in the acquisition and preservation of specimens. This did not stop McCormick repeatedly bemoaning his lack of collecting opportunities (for example, McCormick 1884: 1: 162-163, 338-339) despite the time necessary for the recording of geomagnetic observations, meaning that the expedition remained at some localities for weeks, allowing ample opportunity for excursions ashore.

\section{Kerguelen}

Prior to the Ross expedition's departure, McCormick had been entertained by the eminent geologist William Fitton (1780-1861), a leading figure in the Geological Society of London, who urged that he pay special attention to Kerguelen, should the opportunity arise (McCormick 1884: 2: 280). The reason for Fitton's interest is not clear. Kerguelen had been discovered during French voyages in 1772-1774, but Fitton's curiosity had apparently been aroused by the report that followed James 
Cook's landing in December 1776, although this contained only a brief geological commentary provided by Cook's surgeon, William Anderson (1750-1778). He noted the presence "chiefly of a dark blue and very hard stone" (Beaglehole 1967: 47), but did not identify its volcanic origin.

On 12 April 1840, HMS Erebus arrived at the Kerguelen archipelago, in the southern Indian Ocean (Figure 2), and anchored in Christmas Harbour close to the northernmost point of the main island; she was joined by HMS Terror on the following day. McCormick (1884: 1: 49) was impressed by the landscape, writing that "[Kerguelen], and Spitzbergen, in the opposite hemisphere, constitute, I think, the most striking and picturesque lands I have ever had the good fortune to visit." The sparse, sub-Antarctic vegetation in no way concealed the volcanic nature of the geology, and McCormick recognized eruptive craters surrounded by multiple basaltic lava flows cut by intrusive dykes. Modern research has shown that the volcanism is of Cenozoic age and commenced about 35 million years ago; there are no records of any relatively recent eruptions, but there is geothermal activity (Nougier and Thomson 1990).

Prior (1899: 69) noted that "[b]y far the greater part of the Ross collection consists of specimens from Kerguelen Land", and that "McCormick ... was mainly responsible for the collection of the rock-specimens." The McCormick Bequest of 1890 also contained Kerguelen material. ${ }^{8}$ Approximately 70 specimens were originally present, with the rock types represented including varieties of volcanic lava and agglomerate (basaltic rocks for the most part) and coarser grained intrusive dolerites. Also present are specimens of coal, thermally metamorphosed sedimentary rock and an unusual, olivine-rich mantle xenolith (about five centimetres in diameter) described on McCormick's extant, original label as a "mineral mass from Crater Hill". ${ }^{8}$ Prior (1899) did not include Kerguelen in his petrographical description, considering the Ross and McCormick specimens to have been superseded by the work of the 1872-1876 Challenger expedition. ${ }^{9}$

Despite its overwhelmingly volcanic character, one of the most striking features of Kerguelen's geology is the occurrence of fossilized wood and coal in sedimentary layers between the black, basaltic lava flows, with some substantial tree remains caught-up within the flows. McCormick went ashore with Hooker on 16 May 1840 and in his published account, McCormick (1884: 1: 50-51) implied that it was he who first found the fossil wood. He wrote: "I had the good fortune to discover the first trace of the fossil wood ... loosely scattered on the surface ... I called out to Hooker, who was within hailing distance of me at the time ... to announce this unexpected discovery"; together, McCormick reported, they then "found larger fragments, in situ, beneath the black rock". This may not be the full story. That 1884 autobiographical account is an embellishment of the notes made by McCormick in his expedition journal, wherein there is no mention of calling out to Hooker. ${ }^{3}$ Perhaps McCormick was seeking to reinforce his claim to the discovery in the face of Hooker's subsequent ascendancy, and he may well have had good reason. In a letter to his father, written from Tasmania and dated 16 August 1840, Hooker described McCormick's return from a boat expedition with "numerous splendid Quartz chrystals [sic] \& other zeolites \&c together with lots of coal and fossil wood - the latter we had long before found \& I first detected it lying in immense trunks in the solid basaltic rock". ${ }^{10}$ McCalman (2009: 122) goes further: "[Hooker] found fossilised trees encased in rocks, which the geologist McCormick had overlooked." McCalman also credits Hooker with the discovery of the coal, but, be that as it may, McCormick certainly went on to independently locate coal seams ranging in thickness from a few inches to 
four feet (about 70 centimetres to 1.25 metres). He reported that the coal burnt well, and speculated on its commercial and strategic value (McCormick 1884: 1: 93).

Fossil wood from Kerguelen collected during the Ross expedition was formally described by Seward (1919: 185-186) and Edwards (1921). Albert Charles Seward (1863-1941) established a new species of Dadoxylon from two specimens that may have been collected by Hooker. Edwards assigned McCormick's specimens (mostly contained within the Ross Collection) to Cupressinoxylon: both genera are coniferous. Edwards (1921: 609) described the McCormick material as "forty or fifty pieces of various sizes, some of which are obviously very poorly preserved"; they ranged from carbonized smears on pale grey, sandy mudstone and discrete lignite fragments, to well-preserved pieces of silicified wood. The specimens were originally part of the Ross Collection housed in the NHM petrology department, but following the taxonomic work by Seward and Edwards, they were transferred to and renumbered within the Museum's palaeobotany collection. One example of petrified wood remains in the NHM petrology collection, having arrived there as part of the McCormick Bequest. ${ }^{11}$

Ross (1847: 1: 71-72), probably quoting McCormick (1842a: 28), noted the preservation of sizable tree trunks, claiming that "one exceeding seven feet [2.13 metres] in circumference was dug out and sent to England". This claim was repeated by Edwards (1921: 609), who regretted that the specimen could no longer be found. In fact, nothing that large was sent. The "seven-foot-circumference" tree was very likely to have been the specimen that McCormick (1884: 1: 54) attempted to recover on 25 and 26 May 1840, aided by two sailors armed with pickaxes. This specimen he described as "the large fossil-tree I had discovered", but sadly, once dislodged, "it proved too heavy, silicified as it was, for the strength of the two men to bring [it] down the precipitous ridge, consequently we returned with a smaller one, and some loose specimens." Nevertheless, the specimen recovered was sufficiently large to require the ship's carpenter to construct a crate in which it could be dispatched back to England (McCormick 1884: 1: 86). It was probably much smaller than the "sevenfeet-in-circumference" example but was still the largest specimen collected by McCormick from Kerguelen. Neither it nor the notes that accompanied it can now be located, so Edwards was correct in that respect.

The scientific results of the Ross expedition were regularly sent back to Britain and "Communicated by the Lords Commissioners of the Admiralty" to the Royal Society of London. McCormick (1841: 558-559) provided the first, brief, published account of Kerguelen's geology with mention of the fossilized wood and coal, in a letter which was read before the Royal Society on 22 April 1841. He also prepared an extended account and on 5 October 1840, during the expedition's first visit to Tasmania, he "read a paper on the geology of Kerguelen's Land at the Natural History Society's Meeting" (McCormick 1884: 1: 108). This paper was subsequently published in the Tasmanian Journal of Natural Science (McCormick 1842a), and its text was then incorporated with only minor editorial changes into Chapter 4 of the Ross (1847: 1: 71-80) account of the expedition. Nevertheless, the most striking description of Kerguelen's geology to arise from the expedition probably remains that by Hooker (1844: 219-20), in which he speculated that the time required for the eruption of innumerable lava flows, with the development of a forest on the cooled surface of each before eruption of the next, was "far beyond our powers of calculation". McCormick was probably less impressed than Hooker by the geological evidence for "deep time". In a discursive addition elsewhere in his autobiography (McCormick 1884: 1: 194-195) he opined that "[t]he vast and startling periods of 
time assigned by most geologists to the silent operations of nature ... would seem to be founded on rather questionable calculations", concluding that "thousands may be nearer the mark than the millions of years so often assigned".

Both Hooker and McCormick remarked on the unexpected circumstance that much of the Kerguelen fossil wood was found enclosed within the basalt lava. McCormick (1842a: 28) described the fossil wood as the "most remarkable geological feature of the Island", and "what is still more extraordinary, imbedded in the trappean [lava flow] rocks". In terms of their style of preservation, Hooker (1844: 219) noted that "[t]hroughout many of the lava-streams are found prostrate trunks of fossil trees of no mean growth", but McCormick also described, from a locality visited on 3 July 1840, a coal seam, four feet [1.2 metres] thick, above which "a fossil-tree is imbedded in a vertical position in the face of a perpendicular cliff of greenstone" (McCormick 1884: 1: 85). This may describe a tree encased in basalt lava, but still preserved in its original, upright growth position. Though rare, such a phenomenon has been reported from other volcanic terrains (Bell and Williamson 2017) although not, to the author's knowledge, in the more recent literature from Kerguelen.

\section{Auckland and Campbell Islands}

For the Ross expedition's first voyage towards the anticipated Antarctic continent, Erebus and Terror sailed south from Tasmania on 12 November 1840. About three weeks were spent at Auckland Island, followed by a shorter visit to Campbell Island (Figure 2). Both localities were thickly vegetated, with rock exposures mostly restricted to the coastlines. They were formed of volcanic basalt, some exposures of which showed well-developed columnar cooling structures (McCormick 1884: 1: 131, 138). The Ross Collection contains ten specimens of basalt and dolerite from the Auckland Islands, with an additional specimen within the McCormick Bequest. ${ }^{12}$ Prior (1899: 71-73) described them as either uniformly fine-grained or containing sporadic phenocrysts of feldspar, augite and olivine. From Campbell Island, Prior (1899: 73-75) described basalt, silicified foraminiferal limestone and chert, the latter having been found as pebbles amongst the shingle on the beach. McCormick (1842b: 242) confirms that "several specimens of agate and quartz were picked up on the beach, near which some traces of limestone also appeared." The Campbell Island specimens are all part of the Ross Collection. ${ }^{13}$

The more recent discovery of fossiliferous sandstone beds within the Auckland Island lava succession has demonstrated that the basalt flows there are no more than about 12 million years old (Fleming 1968). A similar age is likely for the Campbell Island basalts. Prior (1899: 74) described the Campbell Island limestone, found as "a vein in the basalt", as having an "essentially modern character"; it was most probably a fissure filling.

\section{The East Antarctic Voyages}

Ross was aware of the reports of land having been located early in 1840 at about $66^{\circ}$ South, to the south of Australia, by a French expedition led by Jules Dumont d'Urville (1790-1842) and an American expedition led by Charles Wilkes (1798-1877). Like Ross, these expedition leaders had been hoping to locate the South Magnetic Pole (Ross 1982: 24-25). In response, Ross set his southward course further to the east and by good fortune was able to penetrate deep into what is known now as the Ross Sea (Figure 2). After some days spent manoeuvring amongst pack-ice and icebergs, land was seen on 11 January 1841 in a latitude of about $71^{\circ} \mathrm{S}$ : "a cluster of white, angularshaped hummocks or small peaks in the background ... having a steep wall or 
escarpment of black rock like lava in the foreground next the sea" (McCormick 1884: 1: 151). The following day, McCormick was in a party that landed briefly on the only accessible spot, a small rocky islet lying just off the mainland, which was named Possession Island. It had a huge colony of Adélie penguins (Pygoscelis adeliae) that attracted most of McCormick's interest: he "knocked down an old penguin with [his] geological hammer, and put him in [his] haversack ... with a few hastily collected specimens of the black lava rock" (McCormick 1884: 1: 154). There are four specimens of volcanic rock in the Ross Collection, with six more included in the McCormick Bequest. ${ }^{14}$ Of the latter, one is notably vesicular, others are of tuff and volcanic breccia (Figure 3). Rowing out to regain the ship, the landing-party passed close to the island's basalt cliffs with McCormick (1884: 1: 155) recording that "[t]here is a beautiful cavern in the face of the rock, with a fine display of columnar basalt, quite a Fingal's Cave in miniature. The columns all most symmetrically vertical". 15

Coasting the newly discovered mountainous land southwards between huge icebergs, the expedition effected a second landing on another island, named Franklin Island. Sir John Franklin (1786-1847) had made his reputation in Arctic exploration, but was Governor of Tasmania between 1836 and 1844 and had provided much assistance to Ross. At Franklin Island, a frustrated McCormick was not one of the landing party. In his stead, Hooker was one of those who attempted to land, but he fell into the icy sea and did not get ashore. Others were more successful and collected five specimens of the volcanic basalt that formed the island for the Ross Collection; one additional specimen found its way to McCormick. ${ }^{16}$

The expedition's most spectacular, and geologically significant, discovery was the active volcano that Ross named Mount Erebus. This is described by McCormick (1847: 416-417):

On the $28^{\text {th }}$ [January 1841 ], in latitude $77^{\circ} 31^{\prime}$, and longitude $167^{\circ} 1^{\prime}$, the burning volcano (Mount Erebus) was discovered, covered with ice and snow from its base to its summit, from which a dense column of black smoke towered high above the numerous other lofty cones and crateriform peaks with which this extraordinary land is studded, from the seventy-second to the seventy-eighth degree of latitude ... Mount Terror, an extinct crater adjoining it, which has, doubtless, once given vent to the fires beneath, attains an altitude little inferior ... and ending in a cape, from which a vast barrier of ice extended in an easterly direction, checking all further progress south.

Ice prevented the expedition from landing close to the volcanoes, and the Ross Sea ice barrier prevented any further progress south. After exploring the barrier for some time, and with the onset of the austral winter, the expedition turned north to milder climes. The closest approach to the South Magnetic Pole had been attained on 18 February 1841, the Pole itself being established as situated inland, within the newly discovered mountainous terrain that the expedition had named "Victoria Land".

The expedition's second Antarctic voyage left New Zealand on 23 November 1841 , McCormick having dispatched the previous week to England "three cases of natural history specimens" (McCormick 1884: 1: 245). As the Antarctic continent was approached, very difficult ice conditions were encountered. No landfall was possible, and the sole "geological" observations made by McCormick arose from pebbles found in the stomachs of seals and penguins that had been killed on the sea ice. As conditions worsened, the expedition came close to disaster when Erebus and Terror 
collided in stormy weather whilst desperately manoeuvring between large icebergs. Thereafter, the expedition was forced to seek safer waters for the winter.

It is surprising that the Ross Sea rock specimens did not attract more attention from the geological establishment when they arrived back in London. They were the first specimens collected by a British expedition from a likely continent well to the south of the Antarctic circle and were closely associated with the spectacular discovery of active volcanism. But, it was 50 years before Prior (1899) described the Possession Island rocks as basalt, tuff and granite. The muscovite-granite is represented only by a small pebble, which Prior (1899: 79) described as "probably derived from the tuff". However, in his fullest account of the geology of Possession Island, McCormick (1847: 416) mentioned only "a volcanic conglomerate, vesicular lava, and basalt, containing imbedded crystals". In respect of Franklin Island, Prior (1899: 79) confirmed that "the specimens collected are all of basalt".

\section{The Falkland Islands}

The expedition's second austral winter was spent in the Falkland Islands and at Hermite Island to the south of Tierra del Fuego (Figure 2); in both localities McCormick was following in the footsteps of his Beagle nemesis, Charles Darwin, but makes no reference to his predecessor's work in his own accounts. The "official" account of the two Beagle exploratory voyages - Narrative of the Surveying Voyages of His Majesty's Ships Adventure and Beagle Between the Years 1826 and 1836 (FitzRoy et al. 1839) - had been published in three volumes (with an appendix to volume 2) in May 1839. Darwin's contribution (1839a) was Volume 3, Journal and Remarks, 1832-1836, and an independent publication of that volume - his Journal of Researches (Darwin 1839b) - was rushed out three months later, shortly before Erebus and Terror sailed. Hooker took a personal copy of Journal of Researches on his voyage, a gift from the eminent geologist Sir Charles Lyell (1797-1875) (Hooker 1899: 187), and it is almost certain that Ross would have had a reference copy of the four-volume set (FitzRoy et al. 1839) aboard Erebus. This is supported in his own account of the Erebus and Terror expedition, where Ross (1847: 2: 260-261) wrote: "The admirable accounts of the Falkland Islands, which have been so recently published by Captain Fitzroy and Mr. Darwin, render any description of them here unnecessary." Even so, specimens of both rocks and fossils from the Falkland Islands were added to the Ross Collection, and additional fossils came to the NHM with the McCormick Bequest. ${ }^{17}$

At the Falkland Islands, like Beagle nine years earlier, Erebus and Terror anchored off Port Louis, in Berkeley Sound, on 6 April 1842. McCormick thought the Falklands a dismal place. ${ }^{18} \mathrm{He}$ made only a few references to geological investigations, and his descriptions show some similarities to Darwin's account. McCormick (1884: 1: 330), reiterating notes made in $1842,{ }^{3}$ wrote that "the geology is very simple, clay-slate and greywacke [a dark, muddy sandstone], passing into sandstone, and the latter again into quartz ... the clay-slate and sandstones containing abundant organic remains of spirifera, orthes, orthoceratites, and stems of encrinites." Darwin (1839: 198) had previously written that "[t]he geological structure of these islands is in most respects simple. The lower country consists of clay-slate and sandstone, containing fossils, very closely related to, but not identical with, those found in the Silurian formations of Europe; the hills are formed of white granular quartz rock ... the quartz insensibly passes into the sandstone."

The Ross Collection contains examples of the sandstone and "quartz rock" - the latter would now be described as an indurated sedimentary quartzite. Most of the 
fossils found were brachiopods, and McCormick's use of spirifera and orthes was appropriate in terms of the nomenclature of the day; encrinites are now known as crinoids. The interesting addition is orthoceratites, indicating a form of nautiloid cephalopod. Darwin (1846) had also collected fossils in the Falkland Islands, and his account of the geology was supplemented by a detailed palaeontological assessment by Morris and Sharpe (1846). They identified and named several varieties of brachiopod and noted crinoids and a fragment from a trilobite, but did not record nautiloids. The nautiloid Orthoceras was subsequently discovered in the Falkland Islands (Clarke 1913: 159), but is known only from localities that were not visited by Darwin or McCormick. A close study of McCormick's fossil specimens confirms that nautiloids are not present, but instead, in three specimens, there are the impressions of the slender, conical shells of tentaculitids (Figure 4). ${ }^{19}$ These may well have been what McCormick took for small, juvenile examples of orthoceratites.

When McCormick arrived back in Britain with his specimens in 1843, Darwin's fossils from the Falkland Islands were being assessed by John Morris (1810-1886) and Daniel Sharpe (1806-1856). It would have been scientifically advantageous to have combined the two collections, but this did not happen, perhaps partly due to continuing personal antipathies. Some of McCormick's specimens went with the Ross Collection to the British Museum in 1844 and then to the NHM, others followed in 1890 with the McCormick Bequest; none were given any attention until the assessments by Stone and Rushton (2007, 2012). After the Morris and Sharpe (1846) examination, Darwin's fossils went to the Museum of Practical Geology (the Geological Survey's museum) but were then transferred to the NHM in 1880. Subsequently, McCormick took no notice of other relevant work, nor did he pass his personal specimens to any recognized authority for assessment. Consequently, he missed the chance to trump Darwin and expand the Falkland Islands' fossil fauna. ${ }^{20}$ Thought by Darwin $(1839,1846)$ to be possibly Silurian in age, it is now regarded as a little younger than that, Early Devonian (about 400 million years old), and is assigned to the Fox Bay Formation in terms of the local lithostratigraphy as currently defined (Aldiss and Edwards 1999; Stone 2016).

\section{Hermite Island, Tierra del Fuego}

Between 8 September and 13 November 1842, Erebus and Terror sailed from the Falkland Islands to Hermite Island, on the south side of Tierra del Fuego and very close to Cape Horn. McCormick (1847: 418-420) thought that the island's "geological structure is very simple, being entirely of plutonic origin". He mentioned a range of lithologies, from "greenstone" (basalt or dolerite) to granite, but apart from noting greenstone "veins" [dykes?] cutting the granite in places, he did not discuss their inter-relationships. Despite the assumed simplicity, McCormick collected avidly, and there are 61 rock specimens from Hermite Island in the Ross Collection, some dated "Oct 1842". ${ }^{21}$ These range from coarse-grained gabbro to fine-grained basalt, with some paler, more granitic types. Darwin, aboard HMS Beagle, had preceded McCormick to Hermite Island, spending Christmas 1832 there, and had described the rocks as greenstone intruded into "baked and altered clay-slate" (Darwin 1839: 212). As with the geology of the Falkland Islands, McCormick could have enlarged on Darwin's geological observations, but having collected the evidence he did nothing with it.

\section{The West Antarctic Voyage}


From Hermite Island, Erebus and Terror returned to the Falkland Islands and spent another month in the Port Louis Harbour area of Berkeley Sound, departing for their third Antarctic voyage on 17 December 1842. This time the destination was West Antarctica, the Antarctic Peninsula (Figure 2). Land was sighted on 28 December, referred to by Ross and McCormick as "Louis Philippe Land". This name had been applied by Dumont d'Urville in 1838 during the French Antarctic Expedition (18371840), but the coast had previously been charted by Edward Bransfield in 1820 and named Trinity Land; this area at the northeast extremity of the Antarctic Peninsula is now generally known as Trinity Peninsula (Hattersley-Smith 1991: 574).

Navigating through difficult ice conditions, Ross's ships reached the southeast side of Trinity Peninsula and an embayment now known as Erebus and Terror Gulf. On 6 January 1843, a party landed on an island at the southern margin of the gulf, although, to his chagrin, McCormick did not go ashore. In his personal account of the expedition (McCormick 1884: 1: 337-338), he consistently referred to the landfall as Pyramidal Island, but Ross (1847: 2: 333) named it Cockburn Island, as it remains (Hattersley-Smith 1991: 158). The island was formed from volcanic rocks, and despite McCormick's absence from the landing party, the Ross Collection contains 21 specimens. ${ }^{22}$ Prior (1899) described the specimens as basalt, and tuff, with granite recovered from an erratic boulder. In addition, fragments were recovered from nearby icebergs. Prior recorded them as volcanic tuff, sandstone and quartzite; all are now part of the Ross Collection. ${ }^{23}$ McCormick (1884: 1: 339) described the collection of one specimen, on 8 January 1843:

We made fast to various large pieces of ice during the day, and one piece, having a quantity of dark mud on it, drifted close alongside of us; and ... in searching the layer of mud I discovered a fine specimen of silicious [sic] rock, of a bottle-green colour very hard, ponderous, and close-grained - a large fragment.

McCormick (1847: 421) referred to this lithology as "hornstone". It was most probably the iceberg-derived erratic described by Prior (1899: 90) as a "greenish-grey compact quartzite ... indistinct flecks of a pale green hornblendic mineral giving the colour to the rock".

\section{Pebbles recovered from penguins and seals}

Cockburn Island was the only landing point on the West Antarctic leg of the voyage, so McCormick had no further opportunity to acquire geological specimens in situ. Instead, he was restricted to continue examining the small pebbles found inside penguins and seals that were killed on the sea ice and then dissected. The Ross Collection contains five such assemblages of small pebbles: three from penguins (probably emperor penguins, Aptenodytes forsteri), two from seals. ${ }^{24}$ The example shown (Figure 5) is dated December 1841 and so was collected from a seal killed during the second of the East Antarctic voyages. However, as early as the Possession Island landing in January 1841, McCormick (1884: 1: 154) noted that he had "often found the stomachs of the penguins, whose skins I have preserved, full of pebbles, as in the seals". He linked this phenomenon with the presence of unusual pebbles found amidst the penguin colony. Prior (1899) identified the lithologies of the pebbles from two seals and two penguins collected in the East Antarctic area in December 1841 and January 1842, and from a penguin caught off "Louis Philippe Land" on 31 December $1842 .{ }^{24} \mathrm{He}$ reported a wide range of lithologies, including sedimentary and metamorphic types, but McCormick had recognized only igneous varieties. 
It has been generally assumed that McCormick failed to realize the importance of the penguin and seal pebbles as being indicative of their Antarctic provenance. For example, Fogg (1992: 87) noted:

McCormick was assiduous in collecting rocks - shooting penguins in order to recover the pebbles from their crops being one method. Had he but realised it, his specimens, which included gneiss, granite, quartzite and slate, proved existence of the continental character of Antarctica ... by the time a petrological description was published [Prior 1899] the material collected by HMS Challenger had made the point. ${ }^{9}$

This assessment is a little unfair. McCormick had certainly considered the pebbles as demonstrating the character of the land to the south, as clearly shown by the following extract (McCormick 1847: 421):

As I had no opportunity of landing for specimens, I was in the habit of examining the stomachs of most of the birds which I shot and preserved for the Government Collection; and found the penguins my best geological collectors, for their crops were frequently filled with pebbles; more especially the large species, Aptenodytes antarctica [the emperor penguin, now A. forsteri]. In one of these individuals I found upwards of a pound [0.45 kilogram] of small fragments of rocks; comprising, basalt, greenstone, porphyry, granite, vesicular lava, quartz, scoriæ, and pumice; but none of them ever brought me a vestige of aqueous [that is, sedimentary] rocks, all were volcanic, and such the appearance of the Antarctic lands, even at a distance, would proclaim them to be. ... As the absence of the sedimentary class of rocks may appear unfavourable to the existence of an Antarctic continent, it must be understood, that my remarks have reference only to the land seen, and that merely the coast-line. Aqueous formations may exist in the interior, beneath the covering of ice and snow; but, it is not the less remarkable, that the land, generally, in the Antarctic regions should present so strikingly the volcanic character.

Without recourse to a microscope and thin-sections of the pebbles (as utilized by Prior (1899), it is easy to understand how McCormick misidentified as exclusively igneous the fine-grained lithologies represented amongst the pebbles.

\section{RESULTS AND CONSEQUENCES}

From a modern perspective, it is astonishing that " $[\mathrm{t}]$ he return of the expedition seems to have occasioned little general interest; the Antarctic was too far away" (Ross 1982: 211). Thereafter, the geological specimens received no attention of significance until it was provoked by "the recent revival in Antarctic exploration" (Prior 1899: 69). The revival had been initiated at the 1895 International Geographical Congress, held in London, which passed a resolution declaring that "the exploration of the Antarctic Regions is the greatest piece of geographical exploration still to be undertaken" (Howarth 1896: 292).

Like the report from Kerguelen, the first account of the expedition's Antarctic geological discoveries appeared in the Tasmanian Journal of Natural Science (McCormick 1842b); it was subsequently incorporated with only minor modification as appendix 4 (McCormick 1847) of the Ross (1847: 2: 412-422) account of the expedition. Based on these accounts, Ross (1982: 244) felt that "McCormick did his [geological] work well." More specialist opinion tended to differ. When the Antarctic rock specimens (from both the McCormick Bequest of 1890 and the Ross Collection 
deposited in 1844) were eventually described in petrographical detail, Prior (1899: 70) was dismissive of McCormick's earlier reports. He stated: "these so-called geological accounts in most cases resolve themselves into exasperating (from a petrological point of view) descriptions of birds, for the doctor appears to have been a more enthusiastic ornithologist than geologist." Prior went on to bemoan "the absence of geological data as to the mode of occurrence and mutual relations of the rocks in the field". Some relevant information could have been gleaned from McCormick's (1884: 1: 3-373) account of the expedition, but his enthusiastic collecting was let down by inadequate field observation and recording.

The botanical results of the expedition were written-up by Hooker and promptly published in 1844. The zoological descriptions were published intermittently in instalments but not concluded for another 30 years (Richardson and Gray 1875), with a review in Nature commenting: "The non-completion of the 'Zoology of the Voyage of the Erebus and Terror' has long been a public scandal" (Anonymous 1875: 289). If McCormick had read the Nature review he would undoubtedly have been incensed to see it continue thus: "Dr. Hooker, under the title of 'Assistant Surgeon' to the Erebus, was the Naturalist of the Expedition, and assisted by Messrs. M'Cormack [sic] and Robertson [surgeon to HMS Terror], the medical officers of the vessels, made an extensive collection of specimens in every department of zoology and botany."

This relegation would have been, to McCormick, one more instance of the prejudice and injustice that he felt had blighted his career, and of which he frequently complained in his autobiographical works. For example, in terms of the Antarctic material: "The same influence stood in the way of my being permitted any share in bringing out the publication of the collections of natural history which I had made with so much toil and labour, not altogether free of personal expense to myself, to say nothing of the risks frequently incurred" (McCormick 1884: 2: 279-280).

But, it may have taken McCormick, by then an elderly man, some time to take note of the Nature review, and respond. Jones (1982: 88) has drawn attention to an anonymous entry (1889: 966) in the Army and Navy Gazette for 7 December that begins: "For some reason or another an attempt has been made in some quarters recently to take away from Dr. McCormick, R.N., the historian of Arctic and Antarctic discovery, the credit of having been naturalist and geologist of the Antarctic Expedition." The complaint went on to list McCormick's contributions in Ross (1847: 1: 46) and concluded: "If the obstacle to a proper recognition of Dr. McCormick's services is to be found in a doubt as to his actual position in the expedition, this proof ought to remove it." Jones suggested that Hooker's fame and scientific recognition were the provocation for this entry, which was presumably included at McCormick's instigation. The celebrity of Darwin, buried in Westminster Abbey in 1882, must also have rankled.

Perhaps as a "public scandal" akin to that attending the zoological results, McCormick would never have seen his geological collections from the Ross expedition described. It was nine years after his death before the petrographical description was published, and, even then, Prior (1899: 69) felt it necessary to qualify the value of the specimens:

The rock-specimens collected during the Antarctic Expedition of 1839-43 were deposited in the British Museum. A few years ago, in the course of a re-arrangement and registration of the rock-specimens in the Museum, this collection amongst others was examined, and microscopic sections of some of the specimens were prepared. Nothing, however, was published at that time, since it was found that the greater part of the collection had been practically duplicated by the rocks of the Challenger 
Expedition, ${ }^{9}$ which had a year or two previously been deposited in the Museum, and it was felt that mere petrographical descriptions of specimens have but little to recommend them in the absence of geological data as to the mode of occurrence and mutual relations of the rocks in the field.

Prior's final statement encapsulated the difficulty with McCormick's work. He collected assiduously, obsessively so at times, but failed to take much interest in, or record, the broader relationships of his specimens; his scientific ambition ran well ahead of his capabilities. Prior restricted his 1899 account to the Antarctic specimens and made no mention of the Kerguelen, Falklands or Hermite Island rocks. McCormick's Kerguelen palaeobotanical material was eventually assessed by Edwards (1921), but the Falkland Islands fossils received no attention until the palaeontological collections from that archipelago were reviewed by Stone and Rushton (2007, 2012). The Hermite Island rocks remain unexamined. Given the circumstances under which the specimens were collected, and despite McCormick's sparse documentation, they deserved better.

For his services to the Ross expedition, McCormick is celebrated by Cape McCormick $\left(71^{\circ} 50^{\prime} \mathrm{S}, 170^{\circ} 58^{\prime} \mathrm{E}\right)$ on the Ross Sea coast of Victoria Land, Antarctica. His ornithological collecting was recognized in the naming (but misspelling) of the South Polar skua, Stercorarius (Catharacta) maccormicki.

\section{ACKNOWLEDGEMENTS}

For assistance at the Natural History Museum, London, I should like to thank Peta Hayes, Zoe Hughes, Adrian Rushton and Epifanio Vaccaro. Helpful reviews by Michael Thomson and Tom Sharpe are gratefully acknowledged. The paper is published by permission of the Executive Director, British Geological Survey (UKRI).

\section{NOTES}

${ }^{1}$ In the caption to his frontispiece, McCormick (1884) gave his age as 52 . He was born on 22 July 1800 , which would date the image to late 1852 or early 1853 , but he spent that period on active service in the Arctic (McCormick 1884). The frontispiece image (Figure 1) is a lithograph enlarged from a daguerreotype, and the latter was most probably created on 20 April 1852, three months before McCormick's 52nd birthday and on the eve of his departure for the Arctic: "the officers of the expedition were expected at Beard's photographic establishment to have their likenesses taken ... [and so] ... on Tuesday, $20^{\text {th }}$, went to Beard's in King William Street, and at noon had my portrait taken hurriedly, in a dress uniform coat" (McCormick 1884: 2: 328). In the portrait he wears the Arctic Medal, but this was not awarded until 1857, so presumably this must have been added to the lithograph when it was copied from the daguerreotype.

${ }^{2}$ Parry reached a farthest north of $82^{\circ} 45^{\prime}$, a record that stood for the next 40 years (Dodge 1973: 107-109).

${ }^{3}$ Wellcome Collection, London (hereafter WCL): MSS 3356-3382, 8682. MSS 3366-3368 cover the 1839-1843 Antarctic expedition.

${ }^{4}$ The Ross Collection, Natural History Museum, London (hereafter NHM), petrology department, with registered specimen numbers relevant to this paper within the range BM 75053-75732.

${ }^{5}$ WCL: MS 3358 (Edinburgh notes, 1830-1831). 
${ }^{6}$ A telling comparison arises from McCormick's accounts of a meeting of the Geological Council of the Royal Society on 2 July 1839. In his diary entry for that day (WCL: MS 3665), he wrote that amongst those attending were "Dr. Fitton (president), Dr. Buckland, Mr Lonsdale; Mr Darwin also present". In contrast, in the autobiography (McCormick 1884: 2 : 280) Darwin is omitted: “... Buckland, Mr Lonsdale, and other fellows present”. Fitton, Buckland and Lonsdale were all well-known geologists of the day.

${ }^{7}$ J. D. Hooker to W. J. Hooker, 17 March 1840. The Royal Botanic Gardens, Kew: Joseph Dalton Hooker Correspondence. JDH/1/2f.26-27. Available at: http://jdhooker.kew.org/p/jdh/asset/1640 (accessed 1 October 2018). ${ }^{8}$ From Kerguelen, the NHM Ross Collection originally included 70 specimens: BM 75053 75207, 75708, 75723-75726, 75732-7574. The McCormick Bequest contained an additional three specimens: BM 66396, 66398, 66399. The olivine-rich mantle xenolith is represented by two specimens: BM 66399 (McCormick Bequest) and BM 75708 (Ross Collection).

${ }^{9}$ The oceanographical expedition aboard HMS Challenger visited and surveyed Kerguelen in January 1874, and subsequently carried out extensive investigations in the Southern Ocean (Moseley 1879).

${ }^{10}$ J. D. Hooker to W. J. Hooker, 16 August 1840. The Royal Botanic Gardens, Kew: Joseph Dalton Hooker Correspondence. JDH/1/2f.31. Available at:

http://jdhooker.kew.org/p/jdh/asset/1654 (accessed 1 October 2018).

${ }^{11}$ Kerguelen plant fossils originally part of the NHM Ross Collection (see note 4) but now held in the NHM palaeobotany collection: V 13612-13631, V 45280-45291. One specimen of petrified wood remains in the NHM petrology collection, BM 66398, having been part of the McCormick Bequest.

${ }^{12}$ Basalt specimens from Auckland Islands: NHM McCormick Bequest: BM 66407; Ross Collection, BM 75252-75256, 75378-75379, 75727-75728.

${ }^{13}$ Specimens from Campbell Island in the NHM Ross Collection: basalt, BM 75251, 75310; flint [despite its flinty appearance the rock is probably not flint], 75697; limestone vein, 75698; quartz, 75699.

${ }^{14}$ Specimens of volcanic rock from Possession Island: NHM Ross Collection: BM 75698, 75700, 75712-75713; McCormick Bequest BM 66416-66419 (Figure 3). The granite pebble is BM 66420.

${ }^{15}$ Fingal's Cave is a celebrated feature eroded into a sea-cliff of Palaeogene columnar basalt on the island of Staffa, western Scotland.

${ }^{16}$ Specimens of basalt from Franklin Island: NHM Ross Collection: BM 75380-75384; McCormick Bequest, BM 66423.

${ }^{17}$ Falkland Island specimens originally in the NHM Ross Collection: BM 75312-75327, 75391, 75704. Fossil specimens were transferred to the NHM palaeontology collection in 1926 and are supplemented by additional specimens from the McCormick Bequest: B 5225252255, BB 17504, BB 19001-19010.

18 "The general aspect of the country is dreary, naked and unprepossessing in the extreme. A monotonous, undulating moorland, consisting of peat-bogs, swamps, and rivulets, or tracts covered with yellowish-brown grass, relieved only by the central ranges of hills of grey quartz." (McCormick 1884: 1: 330).

${ }^{19}$ Tentaculitids occur in McCormick's fossil specimens BB 19001, 19004 and 19007 (Figure 4) (Stone and Rushton 2007, 2012). They are held in the NHM palaeontology collection and most probably arrived at the museum in 1890 with the rest of the McCormick Bequest material.

${ }^{20} \mathrm{McC}$ Cormick might also have expanded the fossil brachiopod fauna. Some of his specimens have been identified as Notiochonetes skottsbergi, following the definition of that species (as Chonetes skottsbergi) by Clarke (1913). From Darwin's specimens, Morris and Sharpe (1846) defined only one "chonetid" brachiopod, Chonetes falklandica, but Clarke (1913: 295) subsequently decided that "there are at least three species of Chonetes in the sandy shales of the Falkland Islands." Clarke did not re-examine Darwin's specimens, and so it is uncertain whether he would have included any of Morris and Sharpe's C. falklandica (now 
Pleurochonetes falklandicus) in his C. skottsbergi. If not, McCormick collected the first specimens of skottsbergi.

${ }^{21}$ The NHM Ross Collection contains 61 specimens of igneous rock from Hermite Island numbered within the range BM 75209 to BM 75711.

${ }^{22}$ Volcanic rocks from Cockburn Island within the NHM Ross Collection: BM 75385-75389, 75665-75680, 75682-75690; BM 75681 is granite from an erratic boulder.

${ }^{23}$ Erratics of volcanic rock and quartz recovered from icebergs and now in the NHM Ross Collection: BM 75258-75261, 75311, 75691-75693, 75729. A specimen of pink quartz from the McCormick Bequest, BM 66422, is described as an Antarctic iceberg erratic but may have become confused with one of McCormick's specimens from Spitsbergen (BM 66375) with which it appears to be lithologically identical.

${ }^{24}$ Pebbles obtained from penguins and seals and now part of the NHM Ross Collection: BM 75262 from penguin, 31 Dec 1842; 75263 from seal, Dec 1841 (Figure 5); 75264 from penguin, 22 Dec 1841; 75265 from penguin, 28 Jan 1842; 75266 from seal, Jan 1842.

\section{REFERENCES}

ALDISS, D. T., and E. J. EDWARDS, 1999. The Geology of the Falkland Islands. British Geological Survey Technical Report WC/99/10. Keyworth.

ANONYMOUS, 1875. [Book review: J. Richardson and J. E. Gray (editors), The Zoology of the Voyage of H. M. S. "Erebus" and "Terror", under the command of Captain Sir James Clark Ross, R. N., F. R. S., during the years 1839 to 1843.] Nature 12: 289-290.

ANONYMOUS, 1889. Army and Navy Gazette, 7 December, p. 966.

BEAGLEHOLE, J. C. (editor), 1967. The Journals of Captain James Cook on His Voyages of Discovery. Volume 3, Part 1. The Voyage of the Resolution and Discovery, 1776-1780. Hakluyt Society Extra Series No. 36. Cambridge, England.

BELL, B. R., and I. T. WILLIAMSON, 2017. Fossil trees, tree moulds and tree casts in the Palaeocene Mull Lava Field, NW Scotland: context, formation and implications for lava emplacement. Earth and Environmental Science Transactions of the Royal Society of Edinburgh 107: 53-71.

CLARKE, J. M., 1913. Fósseis Devonianos do Paraná. Monographia do Serviço Geológico y Mineralógico do Brasil. Volume 1: 1-353.

DARWIN, C., 1839a. Journal and remarks. 1832-1836. In: R. Fitzroy, C. Darwin, and P. P. King, Narrative of the Surveying Voyages of His Majesty's ships Adventure and Beagle, between the years 1826 and 1836, describing their Examination of the Southern Shores of South America, and the Beagle's Circumnavigation of the Globe. Volume 3. London. DARWIN, C., 1839b. Journal of Researches into the Geology and Natural History of the various countries visited by H. M. S. Beagle. London.

DARWIN, C., 1846. On the geology of the Falkland Islands. Quarterly Journal of the Geological Society of London 2: 267-274.

DODGE, E. S., 1973. The Polar Rosses. John and James Clark Ross and Their Explorations. London.

EDWARDS, W. N., 1921. Fossil coniferous wood from Kerguelen Island. Annals of Botany 35: 609-617.

FITZROY, R., C. DARWIN, and P. P. KING, 1839. Narrative of the Surveying Voyages of His Majesty's ships Adventure and Beagle, between the years 1826 and 1836, describing their Examination of the Southern Shores of South America, and the Beagle's Circumnavigation of the Globe. London.

FLEMING, C. A., 1968. Tertiary fossils from the Auckland Islands. Transactions of the Royal Society of New Zealand: Geology 5: 245-252.

FOGG, G. E., 1992. A History of Antarctic Science. Cambridge, England.

HATTERSLEY-SMITH, G., 1991. The history of place-names in the British Antarctic

Territory. British Antarctic Survey Scientific Reports No. 113. Cambridge, England. 
HOOKER, J. D., 1844. The Botany of the Antarctic Voyage of H. M. Discovery Ships Erebus and Terror in the Years 1839-1843. London.

HOOKER, J. D., 1899. Reminiscences of Darwin. Nature 60: 187-188.

HOWARTH, O. J. R., 1896. The International Geographical Congress of 1895. The

Geographical Journal 8: 290-294.

JONES, A. G. E., 1982. Robert M'Cormick, Deputy Inspector-General Royal Navy. The

Great Circle 4: 84-91.

KEEVIL, J. J., 1943. Robert McCormick, R. N. The stormy petrel of Naval medicine. Journal of the Royal Naval Medical Service 29: 36-62.

McCALMAN, I., 2009. Darwin's Armada: Four Voyages and the Battle for the Theory of

Evolution. London.

McCORMICK, R., 1841. Geological remarks on Kerguelen's Land. The London, Edinburgh and Dublin Philosophical Magazine and Journal of Science 18 (Supplement): 558-559.

McCORMICK, R., 1842a. Geological remarks on Kerguelen's Land. Tasmanian Journal of

Natural Science 1: 27-34.

McCORMICK, R., 1842b. A sketch of the Antarctic regions, embracing a few passing remarks, geological and ornithological. Tasmanian Journal of Natural Science 1: 241-247.

McCORMICK, R., 1847. Geological remarks on the Antarctic continent and southern islands. In: J. C. Ross, A Voyage of Discovery and Research in the Southern and Antarctic Regions during the Years 1839-43. Volume 2, Appendix 4. London.

McCORMICK, R., 1884. Voyages of Discovery in the Arctic and Antarctic Seas, and Round the World. 2 volumes. London.

MORRIS, J., and D. SHARPE, 1846. Description of eight species of brachiopodous shells from the Palaeozoic rocks of the Falkland Islands. Quarterly Journal of the Geological Society of London 2: 274-278.

MOSELEY, H. N., 1879. Notes by a Naturalist on the "Challenger", being an Account of Various Observations made during the Voyage of H.M.S. "Challenger" around the world, in the years 1872-1876, under the Commands of Capt. Sir G. S. Nares and Capt. F. T. Thomson. London.

NOUGIER, J., and J. W. THOMSON, 1990. Îles Kerguelen. In: W. E. LeMasurier et al. (editors), Volcanoes of the Antarctic plate and southern oceans. American Geophysical Union Antarctic Research Series 48 (F.5), pp. 429-434. Washington.

PALIN, M., 2018. Erebus. London.

PRIOR, G. T., 1899. Petrographical notes on the rock-specimens collected in Antarctic regions during the voyage of H.M.S. Erebus and Terror under Sir James Clark Ross, in 183943. Mineralogical Magazine 12: 69-91.

RICHARDSON, J., and J. E. GRAY (editors), 1875. The Zoology of the Voyage of H. M. S. Erebus and Terror, under the Command of Captain Sir James Clark Ross, R. N., F. R. S., during the Years 1839 to 1843 . London.

ROSS, J. C., 1847. A Voyage of Discovery and Research in the Southern and Antarctic Regions, during the Years 1839-43. London.

ROSS, M. J., 1982. Ross in the Antarctic. The Voyages of James Clark Ross in Her Majesty's Ships Erebus \& Terror 1839-1843. Whitby.

SAVOURS, A., 2008. McCormick, Robert. In: D. Tatham (editor), The Dictionary of Falklands Biography, pp. 362-364. Ledbury.

SEWARD, A. C., 1919. Fossil Plants. Volume 4. Cambridge, England.

STEEL, E., 2011. He Is No Loss: Robert McCormick and the Voyage of HMS Beagle. British Society for the History of Science, Monograph No. 14. London.

STONE, P., 2016. Geology reviewed for the Falkland Islands and their offshore sedimentary basins. Earth and Environmental Science Transactions of the Royal Society of Edinburgh 106: 115-143.

STONE, P., and A. W. A. RUSHTON, 2007. Fossil collections from the Falkland Islands, 1833-1904: The Beagle, Erebus \& Terror, Challenger and Scotia expeditions. Falkland Islands Journal 9 (1): 124-133. 
STONE, P., and A. W. A. RUSHTON, 2012. The pedigree and influence of fossil collections from the Falkland Islands: from Charles Darwin to continental drift. Proceedings of the Geologists' Association 123: 520-532.

WOODWARD, A. S., and L. FLETCHER, 1904. The Departments of Geology and Mineralogy. In: A. S. Woodward (editor), The History of the Collections Contained in the Natural History Departments of the British Museum. Volume 1, pp. 197-442. London.

Received 7 January 2019. Accepted 26 May 2019.

\section{FIGURE CAPTIONS}

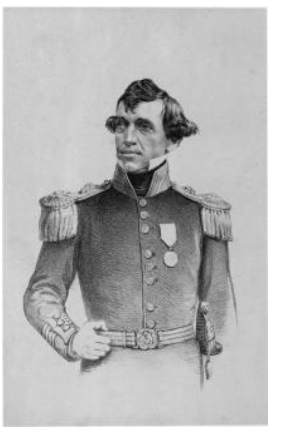

Figure 1. Robert McCormick in 1852. This image was used as the frontispiece of his autobiography and is described as a lithograph enlarged from a daguerreotype (McCormick 1884: 1: ix). National Library of Scotland CC BY 4.0.

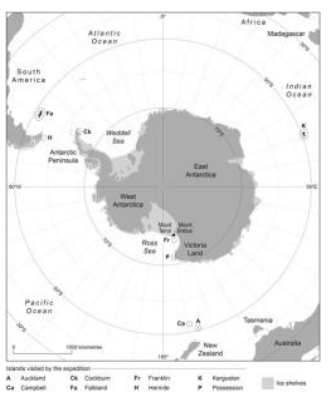

Figure 2. A South Polar projection of the Antarctic continent and Southern Ocean, showing the landfalls of the Ross expedition. Illustration by Craig Woodward, British Geological Survey, Edinburgh. (C) British Geological Survey (UKRI).

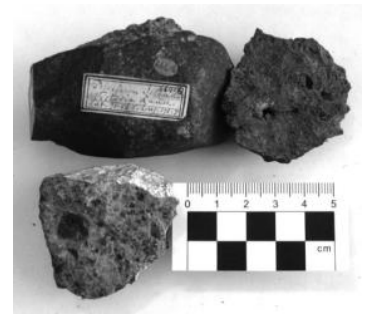

Figure 3. Examples of the volcanic rocks collected by McCormick at Possession Island. Scale in cm. NHM specimens BM 66416, 66417, 66419 (McCormick Bequest). Photograph by Philip Stone. Image prepared for publication by Brian McIntyre, British Geological Survey, Edinburgh. 


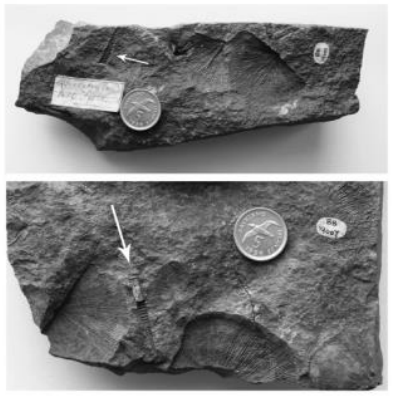

Figure 4. The impressions of tentaculitid shells (arrowed), accompanied by brachiopod impressions, in two of McCormick's fossil specimens from the Falkland Islands. The coin has a diameter of $1.8 \mathrm{~cm}$. NHM specimens BB 19001, 19007. Photographs by Philip Stone. Image prepared for publication by Brian McIntyre, British Geological Survey, Edinburgh.

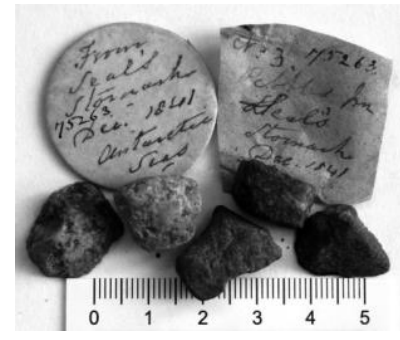

Figure 5. Pebbles recovered by McCormick from the stomach of a seal killed off East Antarctica in December 1841. Scale in cm. NHM specimen BM 75263 (Ross Collection). Photograph by Philip Stone. Image prepared for publication by Brian McIntyre, British Geological Survey, Edinburgh. 